
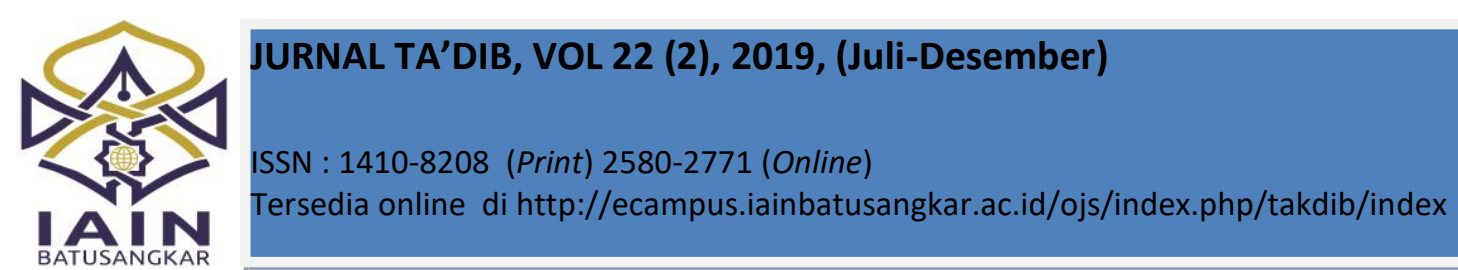

\title{
Pendidikan Islam sebagai Terapi bagi Terpidana Pengguna Narkoba Yayasan Pusat Rehabilitasi Narkoba Ar-Rahman Palembang
}

\author{
Mgs. Nazarudin*) \\ Fakultas Ilmu Tarbiyah dan Keguruan \\ Universitas Islam Negeri Raden Fatah \\ Palembang \\ Email: nazarudin_uin@radenfatah.ac.id

\section{Jumanah} \\ Fakultas Syariah dan Hukum \\ Universitas Islam Negeri Raden Fatah \\ Palembang \\ Email: jumanah_uin@radenfatah.ac.id
}

*) Corresponding Author

\begin{abstract}
The research objective is to restore drug users through the implementation of Islamic education. The research method used was descriptive qualitative method. The informants considered as the data sources were the drug users, their parents, the owner of the rehabilitation center, Yayasan Pusat Rehabilitasi Narkoba Ar-Rahman Palembang, and the local government. The data were analyzed through descriptive normative analysis. The results of this study are 1) rehabilitation is directed at two aspects namely physical and spiritual recovery; 2) the rehabilitation method used is the method of Dhikr and TC (Therapeutic Community) conducted for 6 months; and 3) Islamic education implemented in rehabilitating drug users with a spiritual moral approach includes teaching education on religious foundations, Shalah together, dhikr, and guidance on reading the Qur'an .
\end{abstract}

Keywords: Islamic education, Rehabilitation, Drug Users

PEND

PEAULUAN medis, penyakit jiwa, kesehatan jiwa, dan psikososial. Penggunaan narkoba berdampak pada kerusakan struktur keluarga, masyarakat, dan sekolah baik secara langsung maupun tidak langsung. Lebih jauh lagi, penggunaan narkoba dapat merusak masa depan anak anak bangsa. Dengan kata lain, bahaya penyalahgunaan narkoba tidak hanya terbatas pada pengguna tetapi juga membawa akibat pada kerusakan suatu bangsa.

Pada era 90-an, pengguna narkoba telah menyentuh ke seluruh lapisan masyarakat baik kalangan atas, menengah, maupun bawah. Ditinjau dari kalangan usia, penggunaan narkoba telah menjangkit kalangan remaja, usia dini, maupun setengah baya. Penyebaran narkoba juga sudah sampai hingga ke pelosok desa yang dulunya hanya ada di kota besar tetapi sekarang juga di kota kecil (Sasangka, 2003).

Penyalahgunaan narkoba di Indonesia saat ini sangat mengkhawatirkan. Hal ini berdasarkan laporan Badan Narkotika Nasional pada tahun 2017 yang mencatat bahwa jumlah pengguna narkoba mencapai 3,5 juta orang. Hampir 1 juta orang diantaranya telah menjadi pecandu. Selanjutnya tiap tahun 12 ribu kematian terkait narkoba.

Dampak negative atau bahaya narkoba di Indonesia sangat tidak sejalan dengan nawacita pembangunan Negara Kesatuan Republik Indonesia yakni untuk mewujudkan manusia seutuhnya dan masyarakat yang adil, makmur sejahtera sesuai dengan cita hukum bangsa Indonesia yakni Pancasila. Apalagi kalau pengguna atau pengedar narkoba dilakukan oleh seorang anak. 
Narkotika mempunyai sisi positif di bidang-bidang pelayanan kesehatan dan pengembangan ilmu pengetahuan namun dapat juga berdampak negatif jika disalahgunakan, yang dapat menimbulkan ketergantungan yang besar dan jika tidak dipenuhi akan menyebabkan kematian. Untuk menghindari hal tersebut, pemerintah telah melakukan pengaturan secara hukum dengan mengesahkan Undang-Undang Nomor 35 Tahun 2009 tentang Narkotika sebagai penyempurnaan Undang-Undang Nomor 22 Tahun 1997. Undang-Undang sebelumnya kurang mampu memberikan efek jera baik secara kualitatif maupun kuantitatif terhadap peredaran dan penyalahgunaan narkotika. Oleh karena itu, Undang-Undang ini sebagai pedoman bagi para penegak hukum untuk menjamin ketersediaan obat guna kepentingan ilmu pengetahuan, teknologi, kesehatan serta untuk mencegah penyalahgunaan dan peredaran gelap narkotika (Siswanto, 2012), termasuk dikalangan anak-anak remaja.

Anak adalah harapan bagi orang tua pada masa depan, selain itu anak sebagai buah cinta, generasi penerus, dan harapan bagi negara (Bambang, 2004). Sebagaimana dalam pasal 1 ayat 1 Undang-Undang Nomor 35 Tahun 2014 tentang Perubahan Undangundang Nomor 23 Tahun 2002 tentang Perlindungan Anak dijelaskan anak adalah "seseorang yang belum berusia 18 (delapan belas) tahun, termasuk anak yang masih dalam kandungan (Penyusun, 2014). Dalam usia katagori anak sebagaimana diatur oleh Undang-Undang Nomor 35 tahun 2014 ada sebutan lain yang dapat dipakai adalah remaja.

Seusia tersebut anak atau remaja cenderung lebih banyak menghabiskan waktu di luar rumah, bermain dan bergaul dengan seusia mereka baik di lingkungan rumah, sekolah maupun kelompok. Dengan adanya pengaruh IPTEK yang tidak terkontrol serta pengaruh dari temantemannya anak dapat berperilaku tidak baik dan tidak menutup kemungkinan anak terjebak dalam kelakuan tidak peduli terhadap kepentingan masyarakat yang dapat merugikan dirinya, keluarga dan masyarakat bahkan melanggar hukum seperti penggunaan narkoba.

Golongan anak muda mudah terjerumus dalam penggunaan narkoba, karena masa ini merupakan masa perubahan cepat pada aspek perasaan, kecerdasan, tubuh, sosial, sikap dan kepribadian. Terutama emosi yang tidak stabil dapat membuatnya melakukan perilaku yang nakal (Supramono, 2000).

Hasil penelitian menunjukkan orang tua yang tidak memberikan perhatian dari sisi mental, sosial, dan fisik kepada anaknya akan berdampak pada perilaku anak yang anti sosial yang dapat merugikan individu, keluarga, dan masyarakat. Dampaknya berupa gangguan pemusatan pikiran dan daya ingat, sedangkan dampak sosialnya berupa kerusakan hubungan orang tua. Disamping itu, penggunaan narkoba secara berlebihan/overdosis dapat mengakibatkan kematian. Dampak negatif tersebut perlu mendapat perhatian dan penanganan dari pemerintah dan masyarakat dengan penanggulangan masalah secara preventif dan rehabilitasi (Maulida, 2009).

Upaya preventif merupakan pencegahan secara langsung maupun tidak langsung. Artinya upaya penanggulangan dan pemulihan bagi pengguna narkoba yang mengalami kecanduan. Sedangkan rehabilitasi sebagai usaha pertolongan dan perawatan bagi korban penyalahgunaan narkoba, sehingga ia dapat kembali di masyarakat dengan layak.

Penetapan bagi pencandu narkoba/narkotika merupakan pidana alternatif oleh hakim dan diperhitungkan sebagai masa dalam menjalani hukuman. Pengadilan pidana sebagai wadah penegakkan norma hukum pidana, tidak saja menentukan kepentingan hukum masyarakat dan Negara. Mengenai hal ini dapat dilihat juga dari pendapat P. A. F Lamintang (Adi, 2009), hukum pidana yang umumnya tidak memiliki perbedaan dengan hukum lainnya yaitu, hukum yang dengan beberapa 
ketentuan untuk menjadi agar norma-norma yang diakui untuk ditaati semua orang.

Semua hukum pada dasarnya bertujuan menciptakan kondisi dalam bergaul di masyarakat, baik lingkungan kecil maupun besar. Dengan adanya hukum diharapkan timbul ketertiban, keserasian, dan kepastian hukum. Perlu diketahui meskipun hukum pidana secara umum tidak menunjukkan perbedaan tetapi secara khusus ada yang membedakan yaitu dalam hal pidana (sanksi) inilah hukum pidana harus berhadapan dengan salah satu problemnya. Pidana termasuk juga matregeel, masznahme, suatu yang dirasakan tidak enak oleh orang yang disanksi. Sesudah disanksipun akan merasakan akibatnya. Hukum pidana sebagai Ultimum Remedium (obat terakhir) yang menghendaki, apabila tidak perlu sekali atau masih bisa melakukan upaya yang lain, maka sebaiknya jangan mengunakannya sebagai sarana atau upaya yang dilakukan.

Pemerintah Pusat dan Daerah melakukan kerjasama dalam pencegahan, pemberantasan, dan peredaran gelap narkotika dengan membentuk Badan Narkotika Nasional Provinsi (BNNP) dan Badan Narkotika Nasional Kabupaten/Kota (BNNK). Badan Narkotika Nasional Provinsi ditetapkan oleh Gubernur, sedangkan Badan Narkotika Nasional Kabupaten/Kota di tetapkan oleh Bupati/Walikota.

Pokok masalah yang diangkat dalam penelitian ini adalah tentang Pemulihan Korban Penyalahgunaan Narkoba pada Pusat Yayasan Rehabilitasi Narkoba Ar-Rahman Palembang. Dimana diketahui bahwa pecandu atau korban penyalahgunaan narkotika yang tidak taat aturan, dapat menimbulkan beberapa dampak negatif. Dengan demikian diperlukannya upaya untuk menanggulangi (criminal policy). Banyak anak yang berkonflik dengan hukum dan dimasukkan di lembaga pemasyarakatan. Seharusnya anak-anak tersebut diberikan pembinaan dengan pertimbangan masa depannya.

Berpijak dari penjelasan yang ada, maka hubungan pelaku dan korban kejahatan narkoba pada anak harus dipahami secara cermat guna menentukan langkah-langkah tepat dalam menjatuhkan sanksi pada anak tersebut. Seorang anak pencandu narkoba/narkotika, dapat menjalani pengobatan ataupun perawatan melalui fasilitas rehabilitasi setelah ada ketetapan atau keputusan dari hakim.

\section{METODE PENELITIAN}

Penelitian ini menggunakan pendekatan kualitatif lapangan (field research) yaitu penelitian yang objeknya langsung untuk diperoleh data/informasi terkait realitas upaya rehabilitasi sebagai solusi terhadap pengguna narkoba di Yayasan Pusat Rehabilitasi Narkoba Ar-Rahman Palembang. Sumber data yang digunakan adalah pengurus yayasan, pecandu narkoba, dan orang tua serta pihak terkait seperti pemerintah. Data akan dianalisis dengan teknik analisis deskriptif normatif.

\section{HASIL DAN PEMBAHASAN \\ Hasil Penelitian}

1. Aspek Rehabilitasi bagi Pengguna Narkoba

Dalam melakukan rehabilitasi, ada dua aspek yang ditekankan yaitu sebagai berikut:

a. Pemulihan fisik

Pelaksanaan kegiatan pemulihan fisik dilakukan dengan melakukan senam sehat sekitar 30 menit; sekolah bagi remaja yang memang masih dalam keadaan sekolah; dan pihak Ar-Rahman berupaya mengembangkan potensi pasien agar dapat "survive" di masyarakat nantinya, baik berupa hobi maupun life skill.

b. Pemulihan spiritual keagamaan

Pelaksanaan kegiatan pemulihan spiritual keagamaan, pertama kalinya para pengguna atau pecandu kebanyakan tidak menyadari kalau diri mereka ada masalah, keinginan untuk berubah masih bimbang dan disitulah peran pembimbing untuk 
membantu pasien dengan pendekatan secara fisik maupun secara keagamaan. Pendekatan secara spiritual yaitu dari mengucapkan dua kalimat syahadat, diajarkan salat lima waktu dan sunah, mengaji, menghafal surahsurah pendek dan berzikir.

Tujuan dari pemulihan secara fisik dan spiritual ini karena pada dasarnya seseorang yang dalam keadaan sakit ketergantungan narkoba, dia tidak akan hidup dengan normal dan berpikir dengan waras, sistem syarafnya sudah terganggu dengan obat-obatan tersebut, maka haruslah dipulihkan kembali kehidupannya dengan normal, caranya dengan melakukan pendekatan secara fisik dan secara spiritual keagamaan, agar pasien bisa lepas dari ketergantungan obatobatan dan kelak di masyarakat mereka bisa berguna dan hidup produktif pada umumnya.

2. Metode Rehabilitasi bagi Pengguna Narkoba

Yayasan Pusat Rehabilitasi Narkoba ArRahman Palembang dalam melakukan pemulihan terhadap pengguna narkoba menggunakan metode zikir dan metode TC (Therapeutic Community) yang dilakukan selama 6 bulan dengan penjelaskan sebagai berikut:

a. Zikir

Metode zikir merupakan kegiatan yang bertahap untuk membiasakan pasien untuk berzikir dengan lafal misalnya "Allah" baik lisan, hati, dan perbuatan sesuai dengan tahapan penanganannya di lapangan. Penyadaran melalui zikir merupakan pendekatan keagamaan untuk mengingat Allah dan penanaman nilai spiritual melalui tiga tingkatan zikir. Ketiga tingkatan sebagai berikut:

1) Zikir lisan merupakan zikir dengan pengucapan lafal Allah yang dapat didengar sendiri maupun orang lain. Mengajak pasien untuk berzikir melalui latihan yang kontinu, sebagai tahap awal dengan mengucapkan lafal Allah secara lisan. Zikir ini dilaksanakan sesudah salat Maghrib secara bersama-sama.

2) Zikir hati merupakan zikir dengan hati. Para pasien dilatih untuk mengingat Allah melalui hati yang terkoneksi dengan Allah dimanapun dan kapanpun.

Kegiatan ini dilaksanakan sesudah salat Maghrib dan Subuh tepatnya setelah zikir lisan. Kegiatan ini sebagai sarana pembiasaan bagi pasien untuk mengingatkan Allah di setiap waktu sehingga terhindar dari murung dan melamun.

3) Zikir perbuatan merupakan wujud dari zikir lisan dan hati. Kegiatan ini dilaksanakan melalui kegiatan lapangan sehari seperti kerja bakti, piket, olahraga dan lainnya.

b. Metode TC (Therapeutic Community) Selain metode zikir, di Ar-Rahman juga diterapkan metode TC (Therapeutic Community). Tujuan dari TC ini adalah pemulihan yang dilakukan oleh sesama pecandu itu sendiri dengan menerapkan 5 pilar TC yaitu: 1) family mileu concept (konsep kekeluargaan); 2) peer pressure (tekanan rekanan sebaya); 3) therapeutic session (sesi terapi); 4) religious session (sesi agama); dan 5) role modeling (keteladanan). Pecandu narkoba sangat mudah terkena penyakit, upaya penanggulannya melalui medis. Pecandu yang memiliki penyakit serius/parah maka akan kita rujuk sesuai dengan kesepakatan dengan pihak keluarganya. Dan beragam cara diterapkan dalam pemulihan 
pengguna direhabilitasi Ar-Rahman yang tidak berulang-ulang dengan ketiga metode di atas. Salah satu metode yang terbaru dipakai ArRahman di akhir tahun 2010 adalah PABM (Pemulihan Adikasi Berbasis Masyarakat) dengan implementasi kegiatan terapi rawat inap 1 hingga 5 bulan.

3. Langkah-langkah Rehabilitasi dan Implementasinya di Pusat Yayasan Rehabilitasi Narkoba Ar-Rahman Palembang

Ada 12 langkah yang digunakan dalam rehabilitasi pasien yang dikenal dengan 12 langkah NA (Narcotics Anonymous), Program ini berkaitan dengan kesembuhan fisik, emosional, spiritual, dan mental. Keduabelas langkah tersebut sebagai berikut:

a. Pasien mengakui bahwa dirinya tidak berdaya terhadap adiksi, sehingga hidupnya menjadi tidak terkendali.

b. Pasien menjadi yakin bahwa ada kekuatan yang lebih besar dari diri sendiri yang dapat mengembalikannya kepada kewarasan.

c. Pasien membuat keputusan untuk menyerahkan kemauan dan arah kehidupan kita kepada kasih Tuhan Yang Maha Esa.

d. Pasien membuat inventaris moral dirinya sendiri secara penuh, menyeluruh dan tanpa rasa gentar.

e. Pasien mengakui kepada Tuhan, kepada diri sendiri dan kepada seorang manusia lainnya, setepat mungkin sifat dari kesalahan-kesalahannya.

f. Pasien siap sepenuhnya agar Tuhan menyingkirkan semua kecacatan karakter.

g. Pasien dengan rendah hati memohon kepadaNya untuk menyingkirkan semua kekurangan-kekurangan.

h. Pasien membuat daftar orang-orang yang telah disakiti dan menyiapkan diri untuk meminta maaf kepada mereka semua.

i. Pasien menebus kesalahan secara langsung kepada orang-orang tersebut bilamana memungkinkan, kecuali bila melakukannya akan justru melukai mereka atau orang lain.

j. Pasien secara terus menerus melakukan inventarisasi pribadi dan bilamana kita bersalah, segera mengakui kesalahan.

k. Pasien melakukan pencarian melalui doa dan meditasi untuk memperbaiki kontak sadar dengan Tuhan, berdoa hanya untuk mengetahui kehendakNya atas diri dan kekuatan untuk melaksanakannya.

1. Setelah mengalami pencerahan spiritual sebagai hasil dari langkah-langkah ini, pasien mencoba menyampaikan pesan ini kepada para pecandu lainnya dan untuk menerapkan prinsip-prinsip ini dalam segala hal yang dilakukan (Fajriah, Husaini, \& Adenan, 2016).

Dua belas langkah di atas untuk pemulihan pasien narkoba yang ditawarkan tersebut dapat dipahami bahwa proses pemulihan yang bertahap mulai dari detoksifikasi. Langkah-langkah ini dihapal oleh pasien sebagai pengakuan dan penyadaran. Bagi pasien yang berhasil menerapkan 12 langkah tersebut dapat dikatakan bersih dan waras serta dapat beraktivitas kembali.

4. Peran Pemerintah dalam Merehabilitasi Korban Pengguna Narkoba

Pemerintah Provinsi Sumatera Selatan membentuk BNNP (Badan Narkotika Nasional Provinsi) yang bertugas untuk memberantas kasus-kasus narkoba serta merehabilitasi para pengguna narkoba sebagai implementasi Undang-Undang Nomor 35 Tahun 2009. BNN bersama BNNP gencar melakukan sosialisasi bahaya narkoba dan pemberantasan narkoba di Sumatera Selatan. Masalah BNNP saat ini adalah kurangnya sumber daya manusia untuk memaksimalkan perannya di masyarakat.

Menurut Bustari, Selaku Bidang Rehabilitasi BNN (Badan Narkotika Nasional), bahwasanya pemberatasan narkoba sendiri tidak bisa dipastikan dasar kadar kesembuhan pada korban yang tubuhnya sudah terkontaminasi oleh adikasi, Dan rata- rata Pengguna yang tertangkap 
oleh BNNP itu berkisar usia 15 sampai 55 tahun, dan selanjutnya.

Untuk mengurangi kuantitas pengguna narkoba di Palembang langkah yang dilakukan Pemkot adalah berkunjung menemui para tokoh masyarakat di daerah dan pemerintah. Selanjutnya dilakukan pemberantasan secara kontinu dengan disertai upaya pencegahan.

Kota Palembang terutama daerah pinggiran yang dikenal sarang peredaran narkoba harus diawasi dan ditindak dengan serius. Bandar dan pemakai narkoba yang biasa keluar masuk lembaga pemasyarakatan harus menjadi prioritas untuk diawasi agar tidak mengulangi perbuatan terlarang tersebut. Jika mengulangi kembali harus dihukum seberat-beratnya. Program pencegahan narkoba dapat dilakukan sejak dini mulai TK dan SD dengan pendekatan yang sesuai.

Inti dalam sosialisasi tersebut adalah agar anak-anak memahami bahwa narkoba itu berbahaya. Program ini telah berjalan berbagai provinsi di Indonesia, namun ada beberapa kota/kabupaten yang belum mensosialisasikan bahaya narkoba. Hal ini menjadi sebab maraknya penyebaran narkoba di masyakarat desa.

Pemerintah provinsi dan daerah dapat menginstruksikan kepala dinas untuk memberikan materi tambahan di sekolah tentang bahaya narkoba dan sebagai kejahatan luar biasa. Hal ini penting dilakukan kepada pelajar yang mudah terpengaruh untuk mengonsumsi barang haram ini.

Sosialisasi tentunya tidak dapat dilakukan secara serentak tergatung otonomi daerah. Untuk menambahkan kurikulum narkoba di sekolah, kepala dinas bergandengan dengan polisi dengan pendekatan masing-masing. Upaya ini sebagai upaya pencegahan dari baahaya narkoba.

Pemberantasan narkoba yang menjamur di Indonesia saat sangat mudah untuk dilakukan yaitu melalui penyadaran diri bahwa narkoba sangat membahayakan.
Selain itu perlu melakukan pendekatan diri kepada Tuhan yang Maha Kuasa agar terhindar di narkoba. Maksud dari pendekatan diri adalah pendekatan agama, melalui pendekatan ini ajaran agama sebagai benteng.

Agama mengajarkan bagi penganutnya untuk tidak merusak dirinya sendiri di masa sekarang dan akan datang. Setiap agama juga mengajarkan tentang melakukan kebaikan, menghindari kerusakan diri sendiri, masyarakat dan keluarga. Sedangkan bagi yang telah terjerumus di dunia narkoba diharapkan untuk mengingat kembali nilainilai kebaikan yang diajarkan agama yang diyakini.

Dengan demikian, melalui ajaran agama yang diyakini dan pernah tertanam di hati mampu membangkitkan jiwa untuk kembali ke jalan kebenaran. Pendekatan lainnya adalah pendekatan sosial, pendekatan ini diharapkan dapat memberi penyadaran tentang mereka merupakan bagian penting dalam keluarga dan masyarakat.

Dua pendekatan di atas menyadarkan mereka bahwa kehadirannya penting dalam keluarga dan masyarakat. Pendekatan ini mampu memotivasi hati generasi remaja yang belum menikmati dunia kelam narkoba agar jangan mudah terpengaruh untuk mendekatinya bahkan mengonsumsinya. Bagi yang telah terjerumus, pendekatan ini mampu menyadarkan mereka bahwa hidup ini jangan disia-siakan untuk kenikmatan dunia. Pendekatan psikologis juga menjadi alternatif lainnya. Pendekatan ini diharapkan memberikan penyadaran melalui hati ke hati dengan karakter dan kepribadian masingmasing.

Pendekatan psikologis untuk menamamkan kesadaran diri untuk menjauhi narkoba. Pengguna narkoba yang sudah terlanjur untuk segera kembali kondisi normal, menyusun kembali jalan hidupnya yang hancur menjadi utuh kembali. Maka dari itu, peran dari pemerintah dan masyarakat sangat diharapkan kehadirannya khususnya Provinsi Sumatera Selatan. 
Peran masyarakat terutama diri sendiri sangat diperlukan untuk memerangi dan memberantas narkoba. Sebagian masyarakat terpengaruh dengan mencoba narkoba, mereka tidak mengetahui dampak negatif setelah itu. Pendidikan dan sosialisasi sangat diperlukan saat ini terutama kalangan pelajar.

Generasi terpelajar harus mengambil peran aktif sebagai penerus bangsa. Mereka juga harus mengetahui dampak negatif narkoba bukan mendekati, mencoba, dan mengonsumsinya. Pemerintah sudah berusaha maksimal mungkin untuk memerangi narkoba yang memerlukan dukungan dari masyarakat. Masyarakat Indonesia dikenal dengan patriotismenya yang tinggi. Intinya pemerintah harus menyampaikan bahwa narkoba dapat menghancurkan kehidupan dan masa depan Indonesia.

5. Pendidikan Islam dalam Merehabilitasi Pengguna Narkoba

Pendidikan Islam yang diterapkan dalam merehabilitasi mencakup beberapa kegiatan yaitu:

a. Pengetahuan dasar keagamaan

Pengajaran pengetahuan tentang dasar keagaamaan. Pengajaran dilakukan saat sebelum Zuhur dan setelah Maghrib. Pelaksanaan pengajaran dengan cara yaitu berkumpul di musala dengan membentuk lingkaran dengan duduk bersila. Kemudian pembimbing mulai mengajarkan pengetahuan dasar agama seperti salat, zikir, dan membaca Alquran.

b. Salat berjemaah

Salat berjemaah wajib dilaksanakan sebagai metode penyadaran diri baik salat wajib maupun sunah. Salat sebagai metode yang sangat tepat bagi pengguna narkoba. Saat berjemaah, pembina akan memperbaiki langsung jika ada yang kurang tepat pelaksanaannya.

c. Berzikir
Zikir merupakan metode untuk menenangkan batin juga memohon ampunan atas dosa yang dilakukannya. Dari sisi kesehatan jika, zikir mengandung psikoterapeutik yang mendalam. Dari aspek psikologi, zikir mampu membangkitkan optimisme.

Zikir dilaksanakan melalui 3 tahap yaitu lisan, hati, dan perbuatan. Zikir lisan dengan cara mengucapkan lafal Allah, zikir hati dengan meresapi dalam hati sehingga detak jantung terasa, sedangkan zikir perbuatan dilakukan melalui aktivitas seharihari seperti olahraga dan kerja bakti. Rangkaian zikir tersebut bertujuan untuk menyadarkan jiwa mereka tentang pentingnya agama dalam aktivitas mereka. Lebih jauh, setelah menjalani proses rehabilitasi dapat menerapkannya dalam kehidupan sehari-hari.

d. Membaca Alquran

Membaca Alquran sebagai rutinitas hari bagi pecandu narkoba setelah Maghrib. Pembina membimbing membaca Alquran. Membaca Alquran diawali dengan membaca Al-Fatihah kemudian membaca surat lainnya secara bergiliran. Yang satunya membaca yang lainnya menyimak dan mendengarkan. Tujuan dari membaca Alquran adalah penenangan diri dan perasaan yang sebelumya terganggu.

\section{Pembahasan}

1. Pendekatan Spiritual Keagamaan

Pendekatan spiritual merupakan usaha pemberian bantuan kepada individu untuk mengembangkan bawaannya sebagai makhluk beragama (homo religions), beraktivitas sesuai dengan ajaran agama atau berbudi pekerti, dan mengatasi persoalan kehidupan melalui pemahaman, keyakinan, dan praktik ibadah yang diyakininya. Konseling spiritual bertujuan untuk memfasilitasi dan meningkatkan kemampuan konseli untuk mengembangkan kesadaran 
spiritual dalam penyelesaian masalah. Dengan demikian, konseling dapat membantu pencapaian hidup yang bermakna. Kesadaran spiritual konseli yang baik diyakini akan berpengaruh secara positif dan fungsional terhadap aspek-aspek kehidupan pribadi lainnya (Samsu \& Nurihsan, 2009, p. 83).

Selanjutnya intervensi spiritual bertujuan untuk meningkatkan proses adaptasi dan pertumbuhan spiritual konseli. Hal ini dikarenakan konseling yang tepat sehingga spiritualnya berfungsi secara efektif. Menurut Noor dalam Maesaroh (2009), intervensi mencakup pengetahuan (kognitif), sikap (afektif), perilaku (psikomotorik), dan interpersonal dengan Sang Pencipta. Kesadaran spiritual seseorang tidak berkembang secara otomat, melainkan melalui proses pembelajaran, latihan, dan pengamalan yang berarti melalui pendidikan. Diawali dengan keadaan belum memiliki kecakapan untuk berkomunikasi dengan Tuhan dan sesama manusia. Dengan demikian, konseling diperlukan untuk memiliki kecakapan berkomunikasi dengan Allah melalui kegiatan taat dan beribadah (Samsu \& Nurihsan, 2009, p. 87). Kesadaran agama bagi pengguna narkoba menjadi pedoman terhadap rapuhnya diri remaja dan penguat untuk pemulihannya. Pemulihan pengguna narkoba bukan persoalan yang mudah, butuh waktu yang panjang dan kontinu serta tekad yang kuat dari dirinya.

Dengan demikian, arah pemberian konseling untuk mengembalikan keimanan dan kesadaran agama yang akan meningkatkan kepercayaan dan eksistensi diri sesuai dengan kebenaran yang sesungguhnya dan kemenangan yang kekal untuk meraih kebahagian kehidupan yang sesungguhnya.

\section{Metode Zikir}

Salah satu metode yang digunakan Yayasan Pusat Rehabilitasi Narkoba Ar Rahman dalam pemulihan terpidana narkoba adalah dengan menggunakan metode zikir. Terapi zikir ini dapat digunakan sebagai penyembuhan pecandu narkoba dalam pembentukan Self Awarness (kesadaran diri) pada diri pecandu narkoba, karena seorang pecandu narkoba diyakini sudah tidak memiliki self awareness (kesadaran diri). Dengan menggunakan metode zikir maka self awareness (kesadaran diri) pada diri pecandu narkoba akan terbentuk. Jika self awareness (kesadaran diri) pada diri pecandu narkoba terbentuk maka pecandu narkoba akan berhenti untuk mengkonsumsi dan ketergantungan narkoba, hal ini dikarenakan ia sadar bahwa bahwa mengkonsumsi narkoba adalah larangan agama. Hal ini sesuai dengan pendapat Lystiowati dalam Glenn (2008) yang menyatakan bahwa Self awareness adalah kondisi dimana individu dapat memahami diri sendiri dengan sebenar-benarnya. Individu mempunyai kesadaran mengenai kognitif, afektif, dan evaluasi diri. Individu yang memiliki self awareness baik maka dia akan memiliki control diri yang baik pula. Terapi zikir juga merupakan suatu teknik penyembuhan spiritual dengan cara mendekatkan diri kepada Allah yang mampu menjadikan santri pecandu narkoba dapat berfikir tenang, jernih dan tentram hidupnya. dengan demikian santri pecandu narkoba akan senantiasa memiliki sifat yang stabil dalam segala masalah dan akan berfikir dengan jelas sehingga memungkinkan pecandu narkoba stabil dalam mengahadapi segala masalah, dan dapat memikirkan jalan keluar yang baik maka hal tersebut memungkinkan santri pecandu narkoba tidak akan terjerumus dalam perbuatan negatif yaitu menjadi pecandu narkoba dan akan senantiasa menggantungkan segala masalahnya kepada Allah Swt. Hal ini sesuai dengan fungsi zikir itu sendiri yaitu sebagai sarana mendekatkan diri kepada Allah melalui mengingat-Nya (Subandi, 2009). Selain itu, menurut Subandi, bahwa zikir juga berfungsi sebagai metode psikoterapi, karena semakin banyak berzikir membuat hati tenang, damai, kuat dari dampak lingkungan dan budaya global (Anggraini \& Subandi, 2014). Pada setiap individu terdapat kebutuhan dasar spiritual yang harus dipenuhinya. Seperti yang 
tercantum pada surat Az-Zumar ayat 23: "Gemetar karenanya kulit orang-orang yang takut kepada Tuhannya. Kemudian menjadi tenang kulit dan hati mereka di waktu mengingat Allah." Zikir memiliki daya relaksasi yang dapat mengurangi ketegangan dan mendatangkan ketenangan jiwa. "Setiap bacaan zikir mengandung makna yang sangat mendalam yang dapat mencegah timbulnya ketegangan". Setiap lafal zikir mengandung arti suatu pengakuan iman dan yakin hanya kepada Allah swt. Seseorang dengan tingkat spiritual yang tinggi memiliki keyakinan yang kuat hanya kepada Allah dan yakin dapat menimbulkan kontrol yang kuat dan dapat mengarahkan individu ke arah yang baik." (Anggraini \& Subandi, 2014).

\section{KESIMPULAN DAN REKOMENDASI}

Yayasan Pusat Rehabilitasi Narkoba ArRahman Palembang dalam merehabilitasi pengguna narkoba diarahkan pada aspek fisik dan spiritual keagamaan dengan menggunakan metode zikir dan TC (Therapeutic Community). Para pengguna narkoba juga rehabilitasi dengan pendekatan pendidikan Islam yaitu dasar-dasar keagamaan, salat berjemaah, berzikir, dan bimbingan membaca Alquran.

Beberapa rekomendasi yang perlu mendapat perhatian dari studi ini adalah; pertama, penggunaan metode rehabilitasi lainnya yang bersumber dari temuan penelitian harus menjadi perhatian untuk diterapkan, sehingga peran pusat rehabilitasi menjadi penting. Kedua, kegiatan keagamaan perlu diperbanyak guna memberikan penyadaran akan kesalahannya. Ketiga, peran pemerintah pusat maupun daerah jangan hanya sebatas insidental melainkan berkelanjutan.

\section{REFERENSI}

Adi, K. (2009). Kebijakan Kriminal dalam Penanggulangan Tindak Pidana Narkotika oleh Anak. Malang: UMM
Press.

Anggraini, W. N., \& Subandi. (2014). Pengaruh Terapi Relaksasi Zikir untuk Menurunkan Stres pada Penderita Hipertensi Esensial. Jurnal Intervensi Psikologi, 6(1), 81-102.

Bambang, W. (2004). Pidana dan Pemidanaan. Jakarta: Sinar Grafika.

Fajriah, E., Husaini, H., \& Adenan, A. (2016). Pendekatan Metode Narcotics Anonymous dalam Pemulihan Korban Penyalahgunaan Narkoba di Yayasan Lingkaran Harapan Banua Banjarmasin. Jurnal Berkala Kesehatan, 1(2), 96105.

Glenn. (2008). Mengembangkan Kesadaran Diri (Self Awareness). Retrieved from http://rhythem28.multiply.com

Maesaroh, C. (2009). Pendekatan Konseling Spiritual Untuk Mengembangkan Hikmah Ibadah Bagi Pemulihan Pecandu Napza. Bandung.

Maulida, L. (2009). Kajian Hukum Islam dan Hukum Positif terhadap Kasus Penyalahgunaan Narkotika oleh Anak di Bawah Umur. Jakarta: Fakultas Syariah dan Hukum.

Penyusun, T. (2014). Undang-Undang tahun 2014 tentang Perubahan atas UndangUndang Nomor 23 tahun 2002 tentang. Perlindungan Anak.

Samsu, Y., \& Nurihsan, A. J. (2009). Landasan Bimbingan dan Konseling. Bandung: Remaja Rosdakarya.

Sasangka, H. (2003). Narkotika dan Psikotropika dalam Hukum Pidana. Bandung: Mandar Maju.

Siswanto, S. (2012). Politik Hukum dalam Undang-Undang Narkotika (UU Nomor 35 Tahun 2009). Jakarta: Rineka Cipta.

Subandi. (2009). Psikologi Zikir: Fenomenologi Zikir Tawakal Pengalaman Transformasi Religius. Yogyakarta: Pustaka Pelajar.

Supramono, G. (2000). Hukum Acara Pengadilan Anak. Jakarta: Djambatan. 


\section{Article Metadata:}

Nazarudin, Mgs. Jumanah. (2019). Islamic Education as Theraphy for Covicted Drug Users of Ar-Rahman Drug Rehabilitation Center of Palembang. Ta'dib, 22 (2), 111-120.

http://dx.doi.org/10.31958/jt.v22i2.1428

Keywords: Islamic education, Rehabilitation, Drug Users

Coresponding author: Mgs. Nazarudin, UIN Raden Fatah Palembang,

nazarudin_uin@radenfatah.ac.id 